\title{
Online Determination of Credit Score (PAK) Application Functional Teachers
}

\author{
Rika Melyanti, Muhammad Giatman, Riri Mayliza
}

\begin{abstract}
Determination of Teacher Credit Numbers (PAK) is proposed by the teacher, which are evaluated and evaluated by the Assessment Team. Calculation of credit numbers in PAK still uses manual methods using Microsoft Excel for inputting and Microsoft results as reports, errors in input such as typos and risk of accidental deletion of data still occur frequently. The DUPAK report that will be input into the PAK system is also still waiting for the Assessment Team to send the file to the Pelalawan Regency Education Office so that it takes more time to complete the functional teacher promotion report. To overcome this problem, the credit score calculation process is fast and accurate. A new web-based system, which includes all the elements that are valued by credit numbers. In the old system procedure and the new system it is not much different, the fundamental difference between the new system uses a web-based computer technology in data management that can shorten the data entry process and can overcome the obstacles of the old system.
\end{abstract}

Keywords: credit numbers, determination of credit numbers, DUPAK.

\section{INTRODUCTION}

Promotion of teacher functional positions is part of staffing management which is used as a trigger for employee morale to produce a good performance as well [1]. To submit a proposal for a functional promotion, the teacher must meet the credit score requirements that must be held by the credit score for the functional position. Credit Score is the unit value of each activity item and/or the accumulated value of the activity item that must be achieved by a teacher in the framework of developing a career in rank and position. The higher the credit number owned, the higher the functional position it will hold.

Based on the Regulation of the Minister of National Education No. 35/2010 concerning Technical Guidelines for the Implementation of Teacher Functional Positions and Credit Score, there are 3 (three) main elements and 1 (one) supporting element in granting credit scores. The main elements include education, learning/guidance and certain tasks, continuous professional development and one supporting element, i.e the supporting teacher duties [2]. The

Manuscript received on February 08, 2021.

Revised Manuscript received on March 30, 2021.

Manuscript published on March 30,2021.

* Correspondence Author

Rika Melyanti*, Doctoral Student of Technology and Vocational Education, Universitas Negeri Padang - Indonesia and Lecturer of STMIK Hang Tuah Pekanbaru - Indonesia. Email: camelya2105@htp.ac.id

Muhammad Giatman, Senior lecturers/professors of Technology and Vocational Education, Universitas Negeri Padang - Indonesia: giatman@ft.unp.ac.id

Riri Mayliza, Lecturer of the AKBP-STIE KBP School of Finance and Banking Padang - Indonesia. Email: ririmayliza6@gmail.com

(C) The Authors. Published by Blue Eyes Intelligence Engineering and Sciences Publication (BEIESP). This is an open access article under the CC BY-NC-ND license (http://creativecommons.org/licenses/by-nc-nd/4.0/)
Education Office is one of the government agencies whose activities are related to improving the value and quality of education, manifested in the role of government in improving education, which has been regulated in the 1945 Constitution of the Republic of Indonesia (Amendment IV) which states that every citizen is obliged to attend basic education and the government is obliged to increase it.

By this policy, it is hoped that the quality of educational services in educational institutions in determining the quality of graduates as the main output of the education system can be improved and also by considering the rapid development of technology, the Education Office of Pelalawan Regency needs to have a system that can process and accommodate important data. which will be used as the basis for PAK [3].

Currently, the Pelalawan Regency Education Office is in the process of processing and compiling all existing functional teacher PAK documents, but not yet integrated into a place that can be accessed by many stakeholders. For the current system, the Assessment Team comes to schools to assess Functional Teachers who apply for promotion. And after the assessment is carried out, the Functional Teacher sends the requirements for a promotion to the Pelalawan Regency Education Office. Processing of PAK data is managed manually, i.e inputting and archiving data processing in 2 periods for one year using Microsoft Excel and Microsoft Office applications while waiting for the file provided by the Functional Teacher in the form of submission requirements promotion and data from the Appraisal Team in the form of a Report on the Proposed Credit Score Determination List (DUPAK) before being processed into the PAK to the Pelalawan Regency Education Office. Inputting and determining the PAK data using the Microsoft Excel and Microsoft Office applications has shortcomings in recording such as manual entry, i.e every data that will be stored the information, means that you have to manually type the data into the Microsoft Excel file. Unfortunately, it is not enough to do data entry at one time. If there is a change in data that occurs, then it must re-change, update and add new information related to the PAK. With this condition, there is not yet efficient processing of PAK data. Errors that also often occur include errors in input such as typos and the risk of accidentally deleting data because the data is processed so much while there is no history of data changes made or log data resulting in a lack of accurate information generated, and it takes a lot of time to process the data for PAK. Also, for the data resulting from processing the Proposed DUPAK which is used for archives cannot be seen directly by teachers who apply for promotion, because they have to wait first after an assessment by the Assessment Team and checked by the State Civil Service Agency (BKN).

Published By:

Blue Eyes Intelligence Engineering and Sciences Publication (C) Copyright: All rights reserved. 
By the results of this study, the Pelalawan Regency Education Office as one of the government agencies that play an important role for improving the quality and quality of education by utilizing technology in the industrial era 4.0, it does not yet have an application that can support the processing of PAK data to make it faster and more efficient in terms of time and reduce the error rate. So a web-based application is made, which is an application that can be accessed via the internet or intranet. This application is useful for facilitating the processing and archiving of the determination process of PAK data. Besides, stakeholders in the Pelalawan Regency Education Office can see the results directly anywhere and anytime from processing data that has been processed in the new system.

\section{METHODS}

This research methodology uses the "waterfall" approach, i.e, the work of a system is done sequentially or linearly [4-7]. So each stage must be completed first in full before moving on to the next stage to avoid repetition of the stages. Broadly speaking, the "waterfall" method has the following steps: Requirements Analysis and Definition, System and Software Design, Implementation, Integration and System Testing, Operation and Maintenance [8-14].

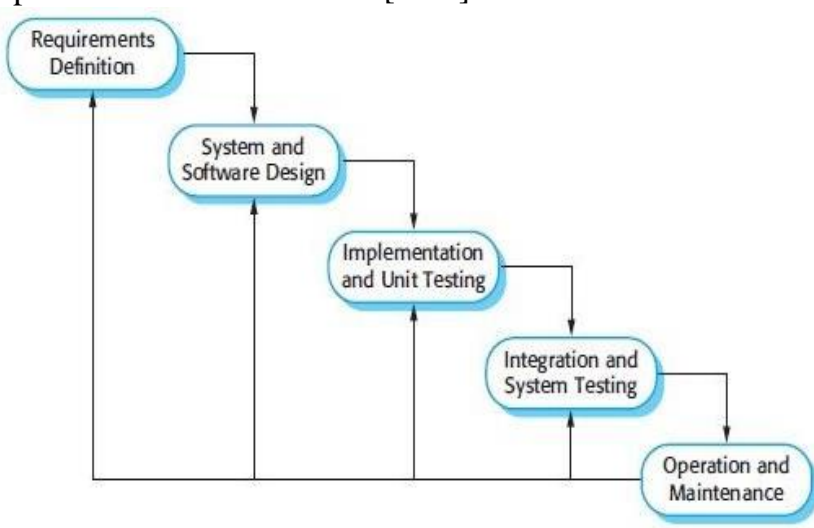

Fig. 1. Research Method

The stages are as follows:

\section{A. Requirement Analysis and Definition}

Requirement Analysis and Definition is the stage of determining the features, constraints and objectives of the system through consultation activity with the General and Personnel Sub Division of the Pelalawan Regency Education Office. These will be defined in detail and serve as system specifications.

\section{B. System and Software Design}

At the System and Software Design Stage, a system architecture will be formed based on predetermined requirements. The identification and description of the basic abstraction of the software system and their relationships in research are carried out by the Sub Division of General Affairs and Personnel of the Pelalawan District Education Office.

\section{Implementation}

At this stage of implementation, the results of the software design will be realized in the General and Personnel Subdivision of the Pelalawan Regency Education Office as a system of PAK program. The program will be tested whether it meets the specifications.

\section{Integration and System Testing}

In the Integration and System Testing stage, the PAK will be integrated and tested as a complete system to ensure the system meets existing requirements. After that, the system can be accessed by stakeholders in the Pelalawan Regency Education Office.

\section{E. Operation and Maintenance}

In this Operation and Maintenance stage, the system is installed and accessible. In this stage, system development is also carried out, such as adding new features and functions.

\section{RESULTS AND DISCUSSION}

This stage is the activity of making a system or application using the assistance of software or hardware by the analysis and design to produce a working system. Furthermore, an evaluation of the test results is carried out, if the test results have errors, then corrections are made. This evaluation is carried out to determine whether the system formed is as desired. After repairs and modifications to the system have been made, the system can be operated.

\section{A. User Login Display}

In this Login Menu, to enter the system, the user must enter the Username and Password that has been registered in the database.

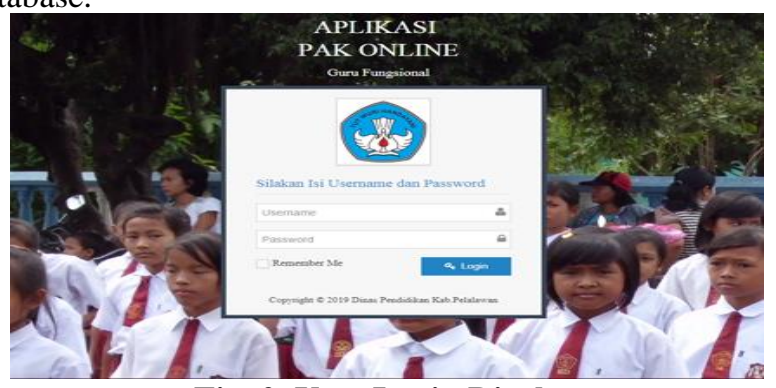

Fig. 2. User Login Display

\section{B. Main Menu Display}

This menu is only used as a menu display after successfully logging into the system as a user.

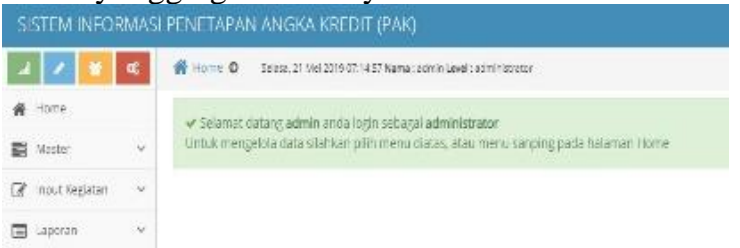

Fig. 3. Main Menu Display

\section{Master Data Display}

The display of master data in the PAK.

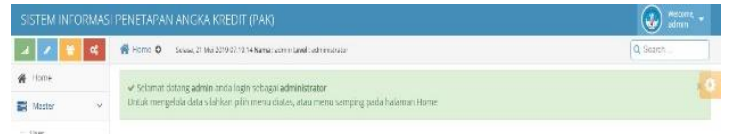

Fig. 4. Master Data Display

Published By:

Blue Eyes Intelligence Engineering and Sciences Publication

(C) Copyright: All rights reserved.

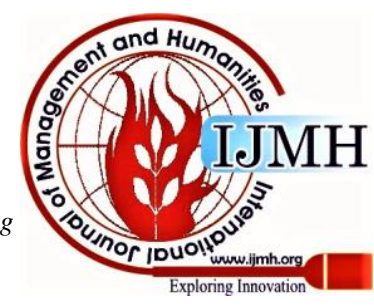


D. User Sub-menu Display

The display of the user sub-menu on the PAK.

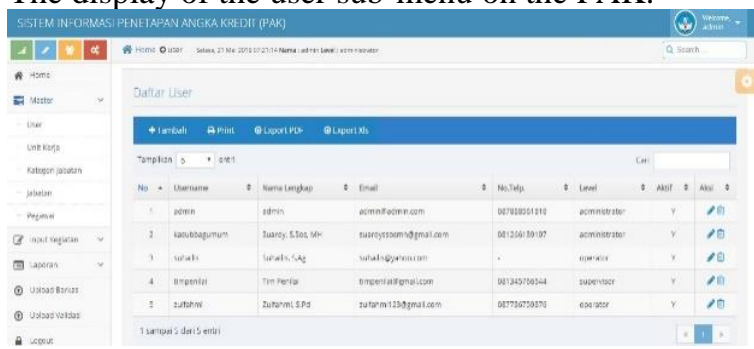

Fig. 5. User Sub-menu Display

E. Display of the Work Unit Sub-menu

The display of work unit sub-menu in the PAK as follows:

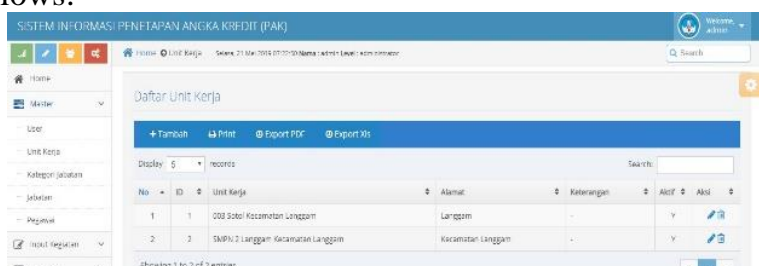

Fig. 1. Display of the Work Unit Sub-menu

F. Display Job Category Sub-menu

Display of job category sub-menu in the PAK.

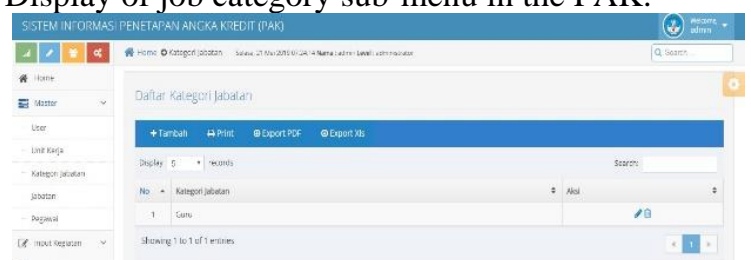

Fig. 7. Display Job Category Sub-menu

G. Job Sub-menu Display

Display of the position sub-menu in the PAK.

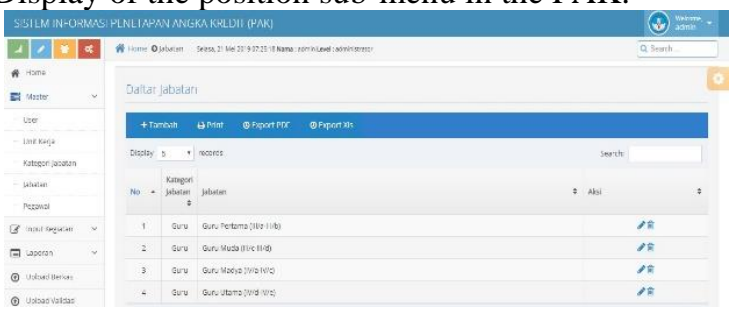

Fig. 2. Job Sub-menu Display

H. Employee Sub-menu Display

Display of employee sub-menu in the PAK.

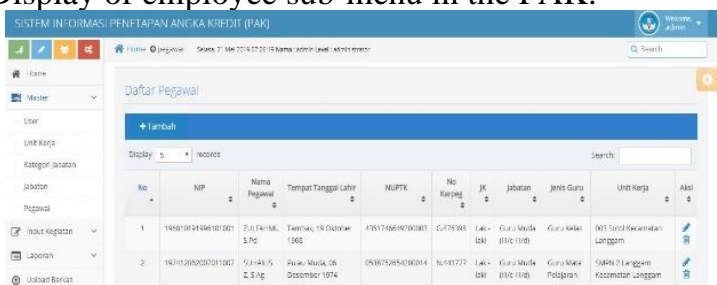

Fig. 3. Employee Sub-menu Display

I. Activity Input Menu Display

Display of the activity input menu in the PAK.

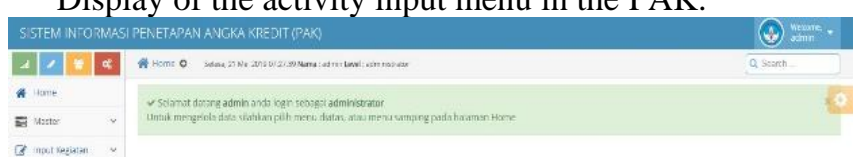

Fig. 10. Activity Input Menu Display

\section{J. Display of DUPAK Activity Sub-menu}

Display of the DUPAK activity sub-menu in the PAK.

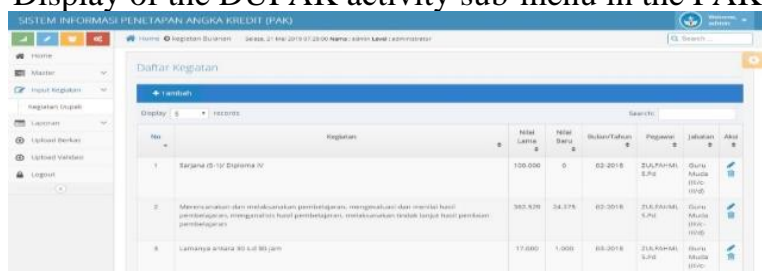

Fig. 4. Display of DUPAK Activity Sub-menu

\section{K. Report Menu Display}

This report menu displays the DUPAK and PAK sub-menus, where the input data is processed.

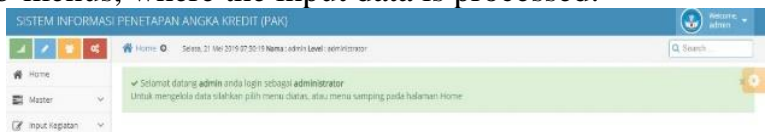

Fig. 5. Report Menu Display

L. Sub-menu Proposer Recap Display

This sub-menu displays data on proposer recap submitting DUPAK.

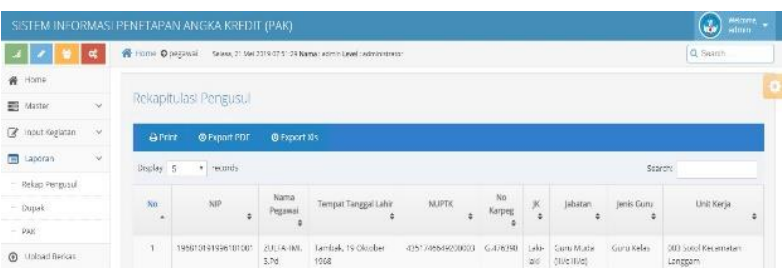

Fig. 6. Sub-menu Recap Proposer Display

\section{Display of DUPAK Sub-menu}

This DUPAK sub-menu displays DUPAK data that has been inputted.

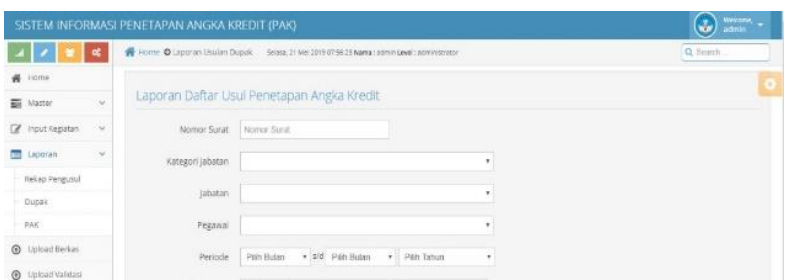

Fig. 7. Display of DUPAK Sub-menu

\section{N. Display of PAK Sub-menu}

This sub-menu displays the grades data taken from the DUPAK that has been inputted.

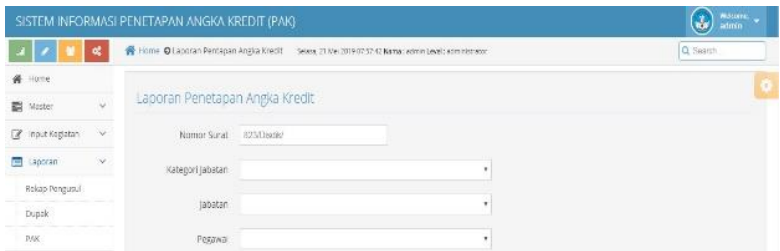

Fig. 8. Display of PAK Sub-menu

\section{O. File Upload Menu Display}

The file upload menu displays the data of requirements files uploaded by functional teachers.

Published By:

Blue Eyes Intelligence Engineering and Sciences Publication

(C) Copyright: All rights reserved.

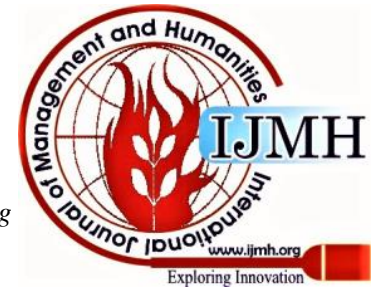




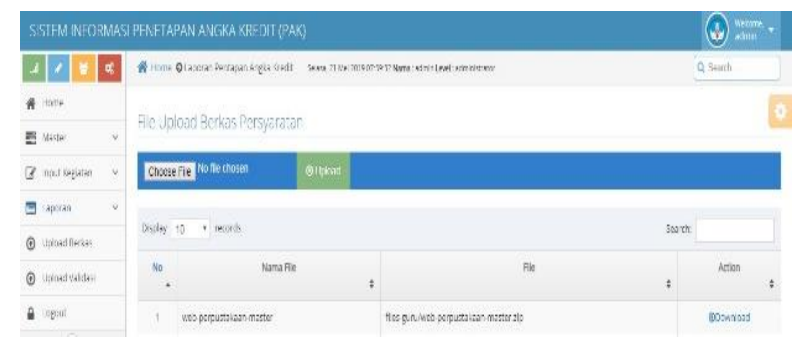

Fig. 9. File Upload Menu Display

\section{P. Upload Validation Menu Display}

On the upload validation menu, the data valued and uploaded by the assessment team is displayed.

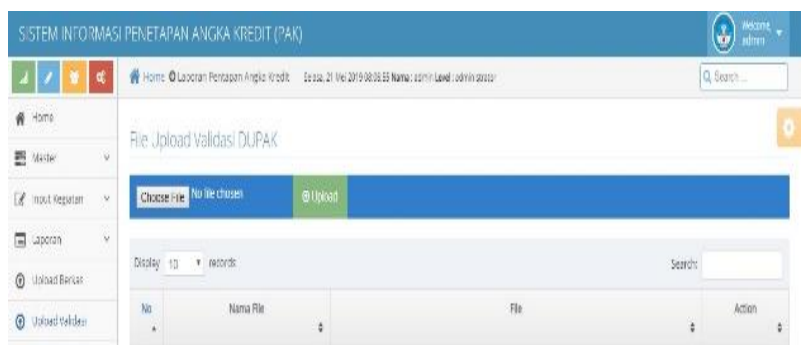

Fig.10. Upload Validation Menu Display

\section{Q. DUPAK Report Display}

This menu displays DUPAK value data that has been entered into the system.

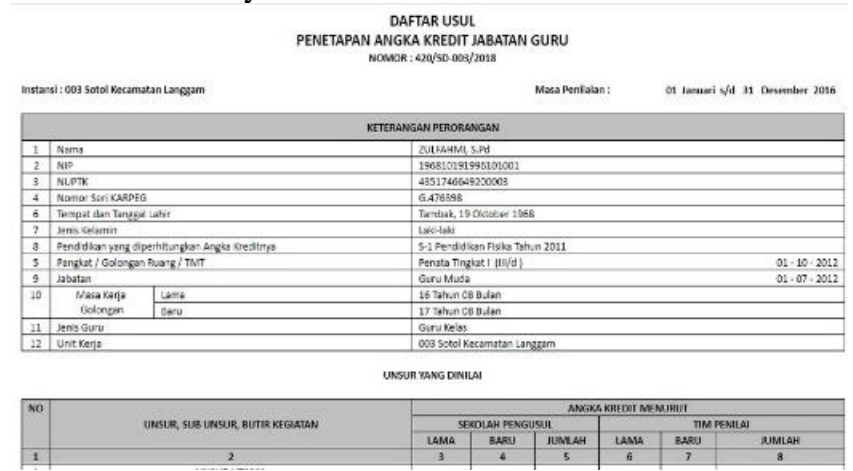

Fig. 11. DUPAK Report Display

\section{R. PAK Report Display}

Displays the PAK value data that has been inputted in DUPAK.

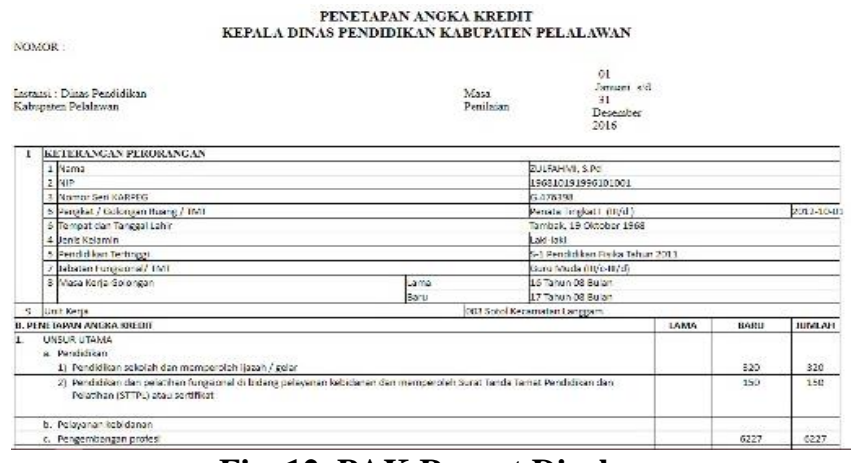

Fig. 12. PAK Report Display

\section{CONCLUSION}

Based on the results of research and discussion, the conclusions that can be drawn from this study are as follows: 1) By the application of the Credit Score Determination
(PAK) data processing application, the input of credit scores becomes systematic and more efficient to be carried out entirely by the functional teacher without the assessment team having to come to schools to conduct assessments; 2) By the data processing application for the PAK, it can help the General and Personnel Subdivision of the Pelalawan Regency Education Office in printing the PAK online with accurate information; 3) By the PAK data processing application, it makes it easier for stakeholders in the Pelalawan District Education Office to submit and process promotion files and information delivery will be faster because they can be accessed anytime and anywhere, as long as there is an internet connection; 4) The data processing application for PAK can be accessed anytime and anywhere by the Head of the General and Civil Service Subdivision of the Pelalawan Regency Education Office, the Assessment Team, Functional Teachers in Pelalawan Regency, and Employees as Administrators.

\section{REFERENCES}

1. N. A Prabowo, N. Hidayah. Sistem Penetapan Angka Kredit untuk Kenaikan Pangkat Guru di Lingkungan Pemerintah Kota Magelang Berbasis Web. Scientific Journal of Informatics, 2(2), 2015, pp. 155-163.

2. A. Mukhid. Meningkatkan kualitas pendidikan melalui sistem pembelajaran yang tepat. TADRIS: Jurnal Pendidikan Islam, 2(1). 2007.

3. Y. Bassil. A simulation model for the waterfall software development life cycle. arXiv preprint arXiv:1205.6904. 2012

4. J. Westland. The Project Management Life Cycle: A Complete Step-by-step Methodology for Initiating Planning Executing and Closing the Project. Kogan Page Publishers. 2007.

5. S. Balaji, M.S Murugaiyan. Waterfall vs. V-Model vs. Agile: A comparative study on SDLC. International Journal of Information Technology and Business Management, 2(1), 2012, pp 26-30.

6. A.M Dima, M.A Maassen.. From Waterfall to Agile software: Development models in the IT sector, 2006 to 2018. Impacts on company management. Journal of International Studies, 11(2), 2018, pp 315-326.

7. R. Melyanti. Aplikasi Pengelolaan Keberangkatan Penumpang pada PT. Indah Travel. Jurnal Ilmu Komputer, 7(1), 2018, pp 15-21.

8. R. Melyanti, M. Iqbal. Sistem Informasi Manajemen Penelitian Dan Pengabdian Masyarakat Di Bagian P3m (Studi Kasus: Stmik Hang Tuah Pekanbaru). Jurnal Ilmu Komputer, 9(2), 2020, pp. 165-176.

9. R. Melyanti R, Y. Andreas. Sistem E-wisata pada Dinas Pariwisata di Kota Pekanbaru Berbasis Android. Jurnal Ilmu Komputer, 6(2), 2017, pp. 124-127.

10. H. Hidayati, Suhardi, D. Irfan, A. Ambiyar, R. Melyanti. Sistem Informasi Pelanggaran Siswa Berbasis Web Menggunakan Rapid Application Development. INTECOMS: Journal of Information Technology and Computer Science, 3(2), 2020, pp. 234-242.

11. Herianto, A. Febriani, R. Melyanti. Sistem Informasi Manajemen Skripsi Mahasiswa Stmik Hang Tuah. Prosiding Seminar Nasional Teknopreneur Universitas Pasir Pengaraian. 1(1), 2018, pp. 253-300.

12. R. Melyanti, D. Irfan, Ambiyar, A. Febriani, R. Khairana. Rancang Bangun Sistem Antrian Online Kunjungan Pasien Rawat Jalan Pada Rumah Sakit Syafira Berbasis Web. INTECOMS: Journal of Information Technology and Computer Science, 3(2), 2020, pp. 192-198.

13. R. Melyanti, D. Irfan, Ambiyar, A. Febriani, R. Khairana, R. Rancang Bangun Sistem Antrian Online Kunjungan Pasien Rawat Jalan Pada Rumah Sakit Syafira Berbasis Web. INTECOMS: Journal of Information Technology and Computer Science, 3(2), 2020, pp. 192-198.

14. R. Melyantri, Herianto. Aplikasi penilaian kinerja dosen dalam Pelaksanaan tri dharma perguruan tinggi. Aplikasi Penilaian Kinerja Dosen Dalam Pelaksanaan Tri Dharma Perguruan Tinggi (Studi Kasus : STMIK Hang Tuah Pekanbaru). 8(10, 2019, pp. 99-106 


\section{AUTHORS PROFILE}

Rika Melyanti is a Doctoral Student of Technology and Vocational Education, Universitas Negeri Padang Indonesia and Lecturer of STMIK Hang Tuah Pekanbaru - Indonesia.

Muhammad Giatman is a Senior lecturers/professors of Technology and Vocational Education, Universitas Negeri Padang - Indonesia words.

Riri Mayliza is a Lecturer of the AKBP-STIE KBP School of Finance and Banking Padang - Indonesia.

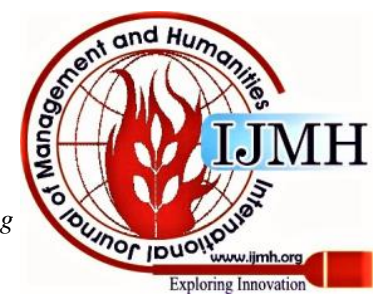

